\title{
Social welfare, justice and distribution
}

\section{An introduction to the special issue in honor of John Roemer}

\author{
Juan D. Moreno-Ternero ${ }^{1}$ - Roberto Veneziani ${ }^{2}$
}

Published online: 27 September 2017

(C) Springer-Verlag GmbH Germany 2017

\section{Introduction}

It is our great pleasure to present this special issue in honor of John Roemer. The contributions collected here are meant as a homage to him and aim to reflect his many contributions to normative economics, political economy, distributive justice, and political philosophy over the last 4 decades.

John Roemer received his A.B., summa cum laude, in Mathematics from Harvard College in 1966 and his Ph.D. degree in Economics from the University of California, Berkeley in 1974. ${ }^{1}$ His first appointment was at the University of California, Davis, where he remained for 26 years (as an Assistant Professor from 1974 to 1978, Associate Professor from 1978 to 1981 and Professor from 1981 to 2000). In 2000, he joined Yale University where he is currently the Elizabeth S. and A. Varick Stout Professor of Political Science and Economics. He has served on the board of editors of several journals, including "Social Choice and Welfare" since 1990. He has been President of the Society for Social Choice and Welfare from 2010 to 2012. He is a Fellow of the Econometric Society and of the British Academy and has held a number of visiting appointments in various universities across the world.

\footnotetext{
1 He was suspended from Berkeley in 1968, due to participation and arrest in a demonstration and an occupation, lost his draft deferment, and taught mathematics in San Francisco secondary schools from 1969 to 1974 , before being readmitted to Berkeley.
}

\footnotetext{
\uan D. Moreno-Ternero jdmoreno@upo.es

Roberto Veneziani r.veneziani@qmul.ac.uk

1 Department of Economics, Universidad Pablo de Olavide, Sevilla, Spain

2 School of Economics and Finance, Queen Mary University of London, London, UK
} 
In the summer of 2015, a 2-day conference took place in London to celebrate John's 70th birthday, and his intellectual contributions, and many of the papers presented at the conference are collected here.

John Roemer's research spans from Marxian Economic Theory to Climate Change and Equity, encompassing Distributive Justice and Political Philosophy, Political Economy, Public Ownership and Market Socialism, as well as Pure Game Theory, Social Choice and International Economics. The sixteen papers collected in this special issue provide a good illustration of the breadth and depth of John's contributions.

\section{Marxian Economic Theory}

John's early years were mostly devoted to Marxian Economic Theory (e.g. Roemer 1977, 1980). John was one of the founders of the so-called "September Group" which comprised social scientists, historians, and philosophers, on the Left and predominantly Marxists at the time, who were engaged in a common project: to re-phrase Marxist questions using modern language, and to address them with contemporary tools of social science and analytical philosophy. ${ }^{2}$ This was later to become known as analytical Marxism—one of the most prominent Marxist schools in the Anglo-Saxon world.

Methodologically, John's key contribution was to show that much of Marxian economics can be derived using modern concepts of equilibrium and optimization: the Marxist phenomena of crisis, exploitation, class and technical change, among others, can be conceptualized as equilibrium phenomena of economies with optimizing individuals. John's models made analytical Marxism a force to be reckoned with in the social sciences. Whatever one thinks of the interpretation of Marx's economics offered there, Analytical Foundations of Marxian Economic Theory (Roemer 1981) remains a classic.

Substantively, it is fair to say that John's most original and lasting contribution to Marxian economics is his reformulation of the theory of exploitation and class (Roemer 1982a, b, c, 1988). First, he showed that, in the general equilibrium of a range of competitive economies, a robust relationship exists between (Marxian) exploitation and class, and between wealth and class (where class is defined not in terms of income, but in terms of relation to the labor process). Then, exploring the normative foundations of the concept of exploitation, he argued that exploitation's injustice is a special case of injustice due to unequal ownership of productive assets.

Two of the articles published in this special issue deal with these topics. In "Marx's Capital Through the Lens of Roemer's General Theory (and Vice-Versa)", Gil Skillman considers how Roemer's theory of exploitation and class has engaged and reframed the historical materialist critique of capitalism initiated by Marx's Capital project. In "Globalisation and Inequality in a Dynamic Economy: An Axiomatic Model of Unequal Exchange", Roberto Veneziani and Naoki Yoshihara provide an axiomatic

\footnotetext{
2 The September Group has comprised, among others, Jon Elster, Adam Przeworski, Robert Brenner, Philippe van Parijs, Hillel Steiner, Erik Olin Wright, and especially, Gerald A. Cohen who has had a profound influence on John's thought.
} 
analysis of Roemer's theory of exploitation using the standard tools of social choice and extend the key insights of exploitation theory to a general dynamic model of the global economy.

\section{Equality of opportunity}

The analysis of the theory of exploitation as the foundation of the Marxian condemnation of capitalism represented John's entry point into the theory of distributive justice and normative economics, starting with Howe and Roemer (1981). He was led to political philosophy in an attempt to understand why Marx's concept of exploitation diagnosed an instance of injustice.

In 1993, John published his most cited paper to date, which contained the seed of his theory of equality of opportunity (Roemer 1993). Traditionally, equality of opportunity was understood as the absence of legal bar to access to education, to all positions and jobs, and the fact that all hiring was meritocratic. This traditional view was mostly challenged in political philosophy to additionally require compensating persons for a variety of circumstances whose distribution is morally arbitrary (e.g., Rawls 1971; Dworkin 1981a,b).

Building on these philosophical contributions, John formalized a precise definition of equality of opportunity in an economic framework as an explicit method of selecting policies among a set of alternatives. In general, a policy can be reduced to a proposal for the allocation of some finite amount of resource across types of individuals sharing circumstances (i.e., aspects beyond the individual's control that influence her status) as a function of the effort (i.e., aspects that also influence the individual's status but over which she has at least some control) they invest. An equal-opportunity policy, with respect to an objective, should allocate the resource so that the degree to which an individual achieves the objective is a function only of her effort, and therefore independent of her circumstances.

John's theory remains extremely influential today ${ }^{3}$ and five papers in the special issue are related to it. In "Equality of Opportunity: How to encompass Fifty Shades of Luck", Arnaud Lefranc and Alain Trannoy explore the issue of luck in the design of equal-opportunity policies. In "Inequality of income acquisition: The role of childhood circumstances", Paul Hufe, Andreas Peichl, John Roemer and Martin Ungerer estimate the effect of circumstances on income acquisition and find that the fraction of inequality attributable to circumstances is larger than in earlier empirical studies. In "Preferences for redistribution and social structure", Erik Schokkaert and Tom Truyts investigate the consequences for redistributive preferences of homophilous reference group formation based on talent. In "Ex Post Inequality of Opportunity Comparisons", Marc Fleurbaey, Vito Peragine and Xavier Ramos propose different criteria to rank income distributions according to an equality of opportunity approach. Finally, in "Gender and inequality of opportunity in Sweden", Markus Jantti, Karin Hederos Eriksson and Lena Lindahl apply the theory to Sweden and find that gender is the

\footnotetext{
3 His 1998 book on the topic (Roemer 1998) has more than 2000 citations, according to Google Scholar.
} 
single most important circumstance in accounting for inequality in long-run income (and opportunities).

\section{Distributive justice}

Although the theory of equality of opportunity represents one of John's main contributions to normative economics, it is difficult to identify a topic in the theory of distributive justice that he has ignored. After more than 20 years, Theories of Distributive Justice (Roemer 1996) remains a magisterial presentation of all of the main approaches and a deep, rigorous and original discussion of some of the key problems in distributive justice. But John has also analyzed issues of axiomatic bargaining (e.g., Fleurbaey and Roemer 2011), intergenerational justice (e.g., Roemer and Veneziani 2004), the veil of ignorance (e.g., Roemer 2002; Moreno-Ternero and Roemer 2008), fair allocation (Roemer 1986; Moreno-Ternero and Roemer 2006, 2012) and public ownership (Moulin and Roemer 1989; Roemer and Silvestre 1993).

Three papers in the special issue deal with these topics. Two of them provide axiomatic analyses of distributive justice. ${ }^{4}$ In "The greatest unhappiness of the least number", Walter Bossert and Kotaro Suzumura analyze a pure social choice problem in which they characterize the least-unhappiness principle, which is formally equivalent to the anti-plurality rule. So do Richard Brady and Chris Chambers in "A spatial analogue of May's theorem", where they establish that the geometric median satisfies Maskin monotonicity, anonymity, and neutrality (uniquely, for three agents) in a spatial model with Euclidean preferences.

From a different vantage point, Woojin Lee and Younghoon Yoon, in "Capital in South Korea: 1966-2013”, deal with the dynamics of capital in South Korea, following Piketty's successful research line, to which John has also paid close attention lately.

\section{Kantian allocations}

More recently, John has started to investigate what an equilibrium would look like in an economy where people are motivated by more public or cooperative concerns, rather than being driven by self-interested utility-maximizing behavior. The starting point of his analysis is the observation of many instances of cooperative behavior, both in the lab and in the economy, contrary to the predictions of the standard maximizing models. One explanation of this behavior assumes that people are standard utility maximizers but are endowed with 'altruistic preferences'. Yet, methodologically, this kind of explanation has an almost circular flavor. Substantively, in large economies one immediately faces a free-rider problem, as the welfare of others is a public good if an agent is an altruist. According to John, this suggests that cooperation, if it comes about, must involve some other optimization protocol which involves some kind of cooperative thinking. Specifically, John has recently proposed that cooperation may

\footnotetext{
4 Due to an unfortunate mistake in the editorial process, these two papers were both submitted to this special issue but appeared in a regular issue of the Journal (Social Choice and Welfare, 2016, Volume 47, Issue 1, pp. 127-139 and pp. 187-205).
} 
involve people engaging in 'Kantian optimization' (e.g., Roemer 2010, 2015) and choose the action that maximizes their payoff assuming that all other agents take the same action. This represents a fundamental departure from Nash behavior-and the related notion of Nash equilibrium - and may provide an alternative framework for thinking about individual behavior in a number of important economic settings.

In "Fairness and the proportionality principle", Alexander Cappelen and Bertil Tungodden deal with the problem of fair allocation and concentrate on a proportional rule somewhat similar to the one introduced by Roemer and Silvestre (1993), which is the intellectual forefather of Kantian equilibria. In "On seeing and being seen", Jon Elster provides a thorough critical discussion of Kantian equilibria, and Kantian behavior, both from a broad philosophical perspective, focusing on Kant's own theory, and from an empirical perspective, reconsidering some of John's own (unpublished) empirical work.

\section{Political economy}

John's interest in inequality and distributive justice naturally led him to explore political competition. He became interested in political science because, as Lipset (1960) famously argued, elections are the democratic form of class struggle.

In all advanced democracies, citizens organize their political competition through parties that compete in general elections. Recently, there has been a growing interest in providing formal models of political competition in general elections. The most commonly used models posit a unidimensional policy space and suppose that competition takes place between candidates whose sole motivation for running is to enjoy the power and privileges of holding office. Both assumptions, however, are quite unrealistic. John's work in this area has mostly been concerned with developing a theory of political competition on a multi-dimensional policy space and with policy-oriented candidates. The core of his theory, which builds around his celebrated concept of Party Unanimity Nash Equilibrium, or PUNE, is summarized in his 2001 book (Roemer 2001), but a range of applications have appeared in independent projects dealing with ambitious themes such as progressive income taxation (e.g., Roemer 1999), the role of democracy to foster equality (e.g., Roemer 2006), the role of racism in determining political outcomes and redistribution (e.g., Lee et al. 2007), and the effect of caste on political competition and corruption in India (Acharya et al. 2015).

In "Relinquinshing Power, Exploitation and Political Unemployement in Democratic Organizations", Carmen Beviá, Luis Corchón and Antonio Romero-Medina present a formal model to analyze the evolution of political power showing that, in some cases, rational agents who value the future may yield political power to another class, whereas in others exploitation is possible.

In "The political choice of social long term care transfers when family gives time and money", Philippe de Donder and Marie-Louise Leroux present a formal model of political choice for long term care which rationalizes an empirically observed fact: low income children provide informal help to their dependent parent while richer children provide financial help. 
In "Peripheral Diversity: Transfers versus Public Goods", Klaus Desmet, Ignacio Ortuño and Shlomo Weber analyze the role of peripheral diversity in the problem of distribution. After micro-founding a new peripheral diversity index, they put forth a simple theory in which the cost of public goods increases with peripheral ethnolinguistic diversity and tax compliance decreases with overall ethnolinguistic diversity.

\section{Climate change}

In more recent years, John has concentrated on the pressing issue of climate change. Mostly in collaboration with Humberto Llavador and Joaquim Silvestre, he has aimed to provide a normative approach to global warming. There are two main issues in climate justice. One concerns the just way to share the scarce global resource of a clean biosphere across generations. The other concerns the just way to share the responsibility of reducing greenhouse gas emissions between countries. It is now widely recognized that no attempt to solve the issues posed by climate change will succeed unless both aspects of the problem are taken into account. In the approach proposed by Llavador et al. (2015), a politically feasible solution to the international allocation problem requires that the dates at which the global South catches up to the global North in income per capita not be delayed from what they otherwise would have been. Subject to this constraint, the concept of sustainability proposed by them-which significantly departs from the predominant discounted utilitarianism-consists in finding an economic path that would maintain human welfare for all future generations, given environmental and technological constraints. They show that a sustainable path does exist in which the global South converges at the required speed, economic growth continues - albeit at a reduced rate-and global emissions of greenhouse gases stay below a reasonable limit.

One paper in the special issue analyzes environmental issues and the notion of sustainability. In "Sustainable Growth", Geir Asheim explores the view that a criterion of intergenerational equity serves to make choices according to ethical intuitions on a domain of relevant technological environments.

Today, we celebrate John's contributions in all of the above fields and hope that he will continue his research for many years to come.

\section{References}

Acharya A, Roemer J, Somanathan R (2015) Caste, corruption and political competition in India. Res Econ 69:336-352

Dworkin R (1981a) What is equality? Part 1: Equality of welfare. Philos Public Aff 10:185-246

Dworkin R (1981b) What is equality? Part 2: Equality of resources. Philos Public Aff 10:283-345

Fleurbaey M, Roemer JE (2011) Judicial precedent as a dynamic rationale for axiomatic bargaining theory. Theor Econ 6:289-310

Howe RE, Roemer JE (1981) Rawlsian justice as the core of a game. Am Econ Rev 71:880-895

Lee W, Roemer JE, Van der Straeten K (2007) Racism, xenophobia and distribution: multi-issue politics in advanced democracies. Harvard University Press and Russell Sage Foundation, Cambridge, MA

Lipset SM (1960) Political man: the social bases of politics. Anchor Books, New York

Llavador W, Roemer JE, Silvestre J (2015) Sustainability for a warming planet. Harvard University Press, Cambridge, MA 
Moreno-Ternero J, Roemer JE (2006) Impartiality, priority and solidarity in the theory of justice. Econometrica 74:1419-1427

Moreno-Ternero J, Roemer JE (2008) The veil of ignorance violates priority. Econ Philos 24:233-257

Moreno-Ternero J, Roemer JE (2012) A common ground for resource and welfare egalitarianism. Games Econ Behav 75:832-841

Moulin H, Roemer JE (1989) Public ownership of the external world and private ownership of self. J Polit Econ 97:347-367

Rawls J (1971) A theory of justice. Harvard University Press, Cambridge, MA

Roemer JE (1977) Technical change and the tendency of the rate of profit to fall. J Econ Theory 16:403-424

Roemer JE (1980) A general equilibrium approach to Marxian economics. Econometrica 48:505-530

Roemer JE (1981) Analytical foundations of Marxian economic theory. Cambridge University Press, Cambridge, MA

Roemer JE (1982a) Origins of exploitation and class: value theory of pre-capitalist economy. Econometrica 50:163-192

Roemer JE (1982b) Exploitation, alternatives and socialism. Econ J 92:87-107

Roemer JE (1982c) A general theory of exploitation and class. Harvard University Press, Cambridge, MA

Roemer JE (1986) Equality of resources implies equality of welfare. Q J Econ 101:751-784

Roemer JE (1988) Free to lose. Harvard University Press, Cambridge, MA

Roemer JE (1993) A pragmatic theory of responsibility for the egalitarian planner. Philos Public Aff 22:146166

Roemer JE (1996) Theories of distributive justice. Harvard University Press, Cambridge, MA

Roemer JE (1998) Equality of opportunity. Harvard University Press, Cambridge, MA

Roemer JE (1999) The democratic political economy of progressive income taxation. Econometrica 67:1-19

Roemer JE (2001) Political competition: theory and applications. Harvard University Press, Cambridge, MA

Roemer JE (2002) Egalitarianism against the veil of ignorance. J Philos 99:167-184

Roemer JE (2006) Democracy, education, and equality. Econometric society monograph series. Cambridge University Press, Cambridge

Roemer JE (2010) Kantian equilibrium. Scand J Econ 112:1-24

Roemer JE (2015) Kantian optimization: a microfoundation for cooperation. J Public Econ 127:45-57

Roemer JE, Silvestre J (1993) The proportional solution for economies with both private and public ownership. J Econ Theory 59:426-444

Roemer JE, Veneziani R (2004) What we owe our children, they their children. J Public Econ Theory $6: 637-654$ 